\title{
Investigating the information needs of sandwich and part-time students of two Public universities in Ogun State, Nigeria
}

\author{
Abayomi Ebenezer Adesoye ${ }^{1}$ \\ Olabisi Onabanjo University, Nigeria \\ adesoyeae@yahoo.com \\ and \\ Oyintola Isiaka Amusa ${ }^{2}$ \\ Tal Solarin University of Education, Nigeria \\ Ishaqamusa@gmail.com
}

\begin{abstract}
This study investigated the information needs and impediments to access to information among the sandwich and parttime students of two public universities in Ogun State, Nigeria. The two universities are Olabisi Onabanjo University (OOU) and Tai Solarin University of Education (TASUED). Questionnaires were used to gather data from 4999 respondents out of 5075 students sampled. The study identified that both male and female pursue part-time/sandwich courses for one reason or another. Their courses of study cut across Arts, Education, Social Sciences, Sciences, and Applied Sciences; and their information needs relate mainly to their studies and other socio-economic issues. The information format preference of the students is both print and non-print. However, their institutional libraries fall short of meeting their information needs due to some problems, prominent among which are inadequate library facilities, and inadequate ICT and library use skill. The study recommended that the universities should recognize the right of their students to access accurate information in the desired formats; provision of practical oriented ICT and library use skill; subscription to electronic resources for the use of staff and students and review of the students' study packs.
\end{abstract}

Keywords: Information needs, information seeking, sandwich/part-time, Olabisi Onabanjo University, Tai Solarin University of Education, Ogun State, Nigeria

\section{Introduction}

The advent of the information age, the desire for higher education and the proliferation of tertiary institutions have brought about the need for distance, part-time, and sandwich education opportunities. Virtually all the tertiary institutions in Nigeria, colleges of education, polytechnics and universities are providing distance or part-time education for the population of the country's citizens. Many of these candidates are among the numerous higher education seekers that could not be admitted into full-time programmes because of the paucity of space. Statistics have shown that one million Nigerian school leavers apply for university admission yearly, but only twenty percent of these applicants are offered admission. Also, individuals who are constrained by jobs and family commitments are also taken care of by the programme.

Singh (1997:42-54) identified distance education as an educational approach which helps to bring education to the doorsteps of a large and varied clientele who cannot benefit from the conventional system of education. This suggests that distance education enlarges educational opportunities by capturing into its fold persons who could not access education due to certain constraints in their life settings and/or in the conventional system of education. Encarta (2007) defines the term distance education as: formal instruction conducted at a distance by a teacher who plans, guides and evaluates the learning process.

Keegan (1997:12-25) concludes that "the major goal of distance education is to provide courses anytime, anywhere, and anywhere there are students or only one student". This approach to education can indeed serve the educational needs of individuals who are still outside the corridors of the conventional system of education for whatever reason. Arising from these definitions, Samalla (2008:269-278) observes that distance education, in its basic form, is characterized by a teacher and learners whose contact with each other is enhanced and performed by a form of mediating technology. He further identifies three variables in a distance education transaction. These are:

- The teacher variable: as a planner, guide, and evaluator of the learning process;

- The learner variable: as a recipient of the planned and guided knowledge and;

- The communication variable: as the channel or medium through items to be learnt are delivered to the learner, and

I. Abayomi Ebenezer Adesoye is Multimedia Resource Librarian at the Olabisi Onabanjo University Library, Ago-Iwoye, Nigeria.

2. Ayitola Isiaka Amusa is a Visiting Lecturer, Department of Library and Information Science.Tal Solarin University of Education, ljebuOde, Nigeria. 
feedback returned to teacher.

Shale and Gomes (1998:2I-25) identify certain features of distance education which makes it suitable to the needs and interests of individuals who are not favoured by the conventional system of education. The features are absence of formal admission requirements; liberal policies with respect to time to complete courses; provision of continuous life-long learning opportunities through part-time study; continuous year-round enrolment and self-pacing; and liberalization or abolition of residency requirements.

As earlier stated in this introduction, institutions that provide distance and part-time learning abound in Nigeria. There are however two national institutions established to provide distance learning. These are National Open University of Nigeria (NOUN) for University education; and National Teacher Institute (NTI) for higher teacher education in affiliation with recognised universities. Other tertiary institutions provide part-time and sandwich courses where students attend classes in the evening, at weekends and during long vacations. The two universities focused on in the study fall into this latter category. They are Olabisi Onabanjo University, Ago-lwoye, and Tai Solarin University of Education, ljebu-Ode. Both institutions are established and funded by the Ogun State government, Nigeria.

The two universities are striving to make the acquisition of degrees more feasible for individuals in the state and outside it who have families and jobs. Also for some individuals who have a desire to further their education to university level but could not secure admission into conventional universities. These universities may have good intentions and policies on their part-time/distance programmes, but their libraries have never at one time or the other conducted a survey of their students regarding their information needs, or the adequacy of the available library services.

Furthermore, the Association of College and Research Library (ACRL) (2000) Guidelines for Distance learning library services strongly recommends that students be surveyed to determine library service needs and user satisfaction. Consequently, this study aims at surveying the part-time and sandwich students of the aforementioned universities. Besides this, it is imperative that the libraries know their users and make efforts to serve them better, more so with the introduction of ICT rapidly changing the information management scene.

Other specific objectives of this study are:

I. To identify the information needs of the students of the universities;

2. To identify the impediments to their information source utilization; and

3. To establish the extent to which the students use electronic information sources.

Based on the stated objectives of this study, the following research questions will be answered through the data gathered. I. What are the demographic variables of the respondents?

2. What are the respondents' reasons for opting for part-time/sandwich courses?

3. What are the library and information needs of the respondents?

4. In what format do the respondents prefer their information sources?

5. What library and information facilities are available to the respondents?

6. What are the impediments facing respondents in their use of library facilities of their respective universities?

7. Are the respondents skillful in information and ICT literacy?

\section{Literature review}

Ault (2002:39-48) observes that at the advent of the new millennium and in the midst of the information age, distance education underwent rapid and widespread change. This is further enhanced by faster and easily accessible information. Information is now easily accessible at fast speed, and that has meant more people could have the benefit of information and education.

Cooke (2004:47-57) concludes that the provision of library services to non-regular and remote users can be involved. Consequently, the library should understand distance and adult learners. He further advises that librarians must create policies and procedures specific to distance learning; they must coordinate programme correspondents such as document delivery and reference services; they are supposed to market their services; they need to continually evaluate the best information resources; they must create and maintain websites, and they should collaborate with faculties, administrators and other librarians.

Distance education or part-time students as a group of information users have specific information needs and information seeking behaviours. Several studies have been conducted into these. Jaggen, Taliman and Waddell (I999: I3 I175) observed that despite the wide variety of materials available to distance learning students, more students used the instructor-provided materials than any other source available. Another study by Stabch (1994) noted that while the public Inkanyiso, Jnl Hum \& Soc Sci 2010, 2(2) 
library was used most often by distance education students for books and journals, the students surveyed did use their home academic library as their primary source for article databases.

Shouse (1995:355-362) identifies convenience as the most important factor in distance students' information source selection. She reported higher overall use of the public library distance learning students with convenience cited as the most important factor in information source selection.

In a survey of distance learning faculties and graduate students, by Cassner and Adams (1998: 355-362), they found that the libraries of other institutions were used more frequently than the library at their respective institution as convenient to them. Closely related study were conducted by the trio of Unwin, Stephens and Bolton. In the study, parttime students and faculty were found to use the public libraries more frequently than the libraries of their home institutions. Among the reasons provided are time, distance, convenience and lack of institutional collaboration.

Newton (2007: 140-464) examined the potential and actual roles that academic librarians play in supporting the development of information literate off-campus learners in Scotland and the United Kingdom. The study concludes that the most critical issue to be addressed is the integration of academic library professionals within course teams. The librarians are willing to become involved in teaching and to take responsibility for the delivery of information literacy courses for off-campus learners, but in order to do so effectively they must operate and interact with students within the same learning space as the academic staff.

On the African Scene, Kavulya (2004) looked into the challenges of providing library services for distance education students. Three universities in Kenya were selected for the study. He commended the efforts of the universities in making provision for distance education learners and advocated collaboration between information personnel and those who design and implement distance education programmes. He however emphasized that distance education students needed adequate library services if they were to gain quality education

Mabawonku (2004:15I-166) conducted a survey of library use in distance learning in three Nigerian universities. The study concluded that the universities studied did not adequately provide for the library needs of the students. Also in Nigeria, Aramide and Ayankola (2008:I) conducted a study into ICT application and utilization for distance and open learning. The study identified ICT facilities available for distance learning at the National Open University of Nigeria, the use they are put to and factors that hinder effective use of ICT in the university. The study in conclusion recommends the provision of adequate ICT infrastructure and training and re-training of the course facilitators in the university.

Furthermore, Boadi and Letsolo (2004:189-199) investigated the information needs and information seeking behaviour of distance learners at the Institute of Extra-Mural studies in Lesotho. They reported that the students' sources of information were colleagues, personal collections and family members. They use the on-campus library resources less because access to them is not easy.

Lastly, on the African scene, Oladokun and Aina (2009:43-50) looked into the library and information needs and barriers to the use of information sources by continuing education students at the University of Botswana. Their study aimed at identifying the library and information needs of the part-time evening students; establishing the computing and information skills of the part-time evening students. The study found that the major areas of information needs of the respondents are related to course of study, job opportunities, career development and further education. The study also found that the university library does not adequately cater for the library and information needs of the students. The study however recommends that the University of Botswana library should ask for space in the local public libraries, and that school libraries keep some materials for the distance learning students' use.

Information Technology (IT) plays crucial roles in providing library and information service to part-time/distance learning students. Gopakumar and Baradol (2009: 61) submitted that:

The web opens new windows of opportunity to provide information support to distance learners. Electronic documents can be made available anywhere and anytime those two computers can connect. What makes this possible is the ubiquitous World Wide Web. With the technology of the Web, library documents can be viewed and printed by any person who has a web connected computer, whether that person lives nearby or in another distant location.

Furthermore, e-mail makes it easy to contact anybody at anytime in the world in few seconds.

In an earlier study conducted by Neimi, Ehrard, and Neeley (1998:20), they concluded that:

What distance learners expect of libraries is the ability to search periodical indexes, abstracts, Compact Disc Read-Only-Memory (CD-ROMs) and bibliographic services such as the Educational Resources Information Centre (ERIC); do electronic book check out and renewal over the telephone (toll free); deliver photocopies, the results of literature searches; internally track and deliver all inter library loan services; and establish an electronic feedback system. 
Some library and information services that can be offered to the part-time distance learners identified by Gopakumar and Baradol (2009) are:

- Library websites as a service point

- Online Public Access Catalogue (OPAC)

- Document delivery through regional study centres

- Electronic reference

- Access to e-journals

- E-Reserve

- Information literacy

- Online reference sources.

Empirical studies on IT and distance learning have revealed that distance students were following the same trends that had been observed in the traditional population. These are changes in part-time students' usage pattern which now favour the use of electronic resources, the Internet in particular (Thompson, 2007:7). Kelley and Orr (2004: I 75- I9I) also noted that:

The technologies may change but, at the same time, students overwhelmingly prefer to have instruction delivered in a format that is accessible off-campus and offers them flexibility in when they receive instruction.

Also, Mclean and Dew (2004:265-303) found that electronic resources were favoured over instruction. Their reasons for this may not be unconnected with the advantages of e-resources postulated by Lee (2002). These advantages are:

- Speed of access to the latest information

- Ability to incorporate multimedia elements

- Quick searching

- Linking from and to other sources (hypertext capability)

- Security (no fear of loss)

- Multi-user capability

- Downloading and printing the article is very easy.

Liu and Yang (2004:24-35) conducted a survey of graduate students in distance learning regarding their use of information resources. The study specifically focuses on the factors that lead to information resource selection. The study found that the respondents overwhelmingly used the Internet as their primary source of information and cited speed as their number one concern in selecting a primary information source.

\section{Research methodology}

This study employs the survey method to investigate the information needs of sandwich and part-time students of Olabisi Onabanjo University (OOU) and Tai Solarin University of Education (TASUED). The two universities are owned by the Ogun State Government, Nigeria. They are located about $30 \mathrm{~km}$ away from each other. OOU is a conventional university offering courses in arts, education, science, social sciences, engineering and technology, agricultural sciences, law and medicine. TASUED on the other hand is a specialized university. It offers arts, sciences, social sciences, technology, agriculture, and vocational education.

By the 2008/2009 academic session, the total population of the category of students in focus (part-time/sandwich) in OOU is 9,617 (estimate); and 7,300 in TASUED, totaling 16,917 students. A proportional sampling method was used to select $30 \%$ of the students in each of the universities. As such, 5, 075 students, (OOU 2885, and TASUED 2, I 90 ) were selected as population sample.

Questionnaire was the main instrument used to gather data from the population sample. 5,075 copies of the questionnaire were produced and randomly administered to the respondents in the universities. The exercise lasted 20 working days. Descriptive statistics were used to analyze the data collected through the questionnaire. The rate of response to the questionnaire was encouraging; 4,999 copies of the questionnaire were duly completed and returned. This figure represents $98.5 \%$ of the total copies administered. Breakdown of this figure shows that 2,737 (55\%), and 2,262 (45\%) responses were received from OOU and TASUED respectively.

\section{Results and discussions}

Analysis of the demographic data of the respondents revealed that 2,627 respondents (52.50\%) are male and 2,372 (47.50\%) are female. Their age distribution ranges from 20-59 years. Specifically, the majority, 2,043 respondents (40.87\%), are between $25-39$ years; 1,670 respondents (33.4l\%) fall within 20-24 years age group; 976 respondents (19.52\%) are between 40-44 years; and the remaining $310(6.20 \%)$ are over 44 years. These findings indicate that sandwich/part-time courses are being undertaken by both male and female students, a majority of whom are mature Inkanyiso, Jnl Hum \& Soc Sci 2010, 2(2) 
candidates between age 25-39. However the programme also attracts younger candidates. (See Tables I \& 2 and figure I \& 2 ).

Table I Distribution of respondents by sex $(N=4999)$

\begin{tabular}{|l|c|c|}
\hline \multicolumn{1}{|c|}{ Sex } & Frequency & Percentage \\
\hline Male & 2627 & 52.50 \\
\hline Female & 2372 & 47.50 \\
\hline Total & 4999 & 100 \\
\hline
\end{tabular}

Table 2 Distribution of the respondents by age $\operatorname{group}(\mathrm{N}=4999)$

\begin{tabular}{|l|c|c|}
\hline \multicolumn{1}{|c|}{ Age Group } & Frequency & Percentage \\
\hline $20-24$ & 1670 & 33.41 \\
\hline $25-39$ & 2043 & 40.87 \\
\hline $40-44$ & 976 & 19.52 \\
\hline $45-59$ & 310 & 6.20 \\
\hline Total & 4999 & 100 \\
\hline
\end{tabular}

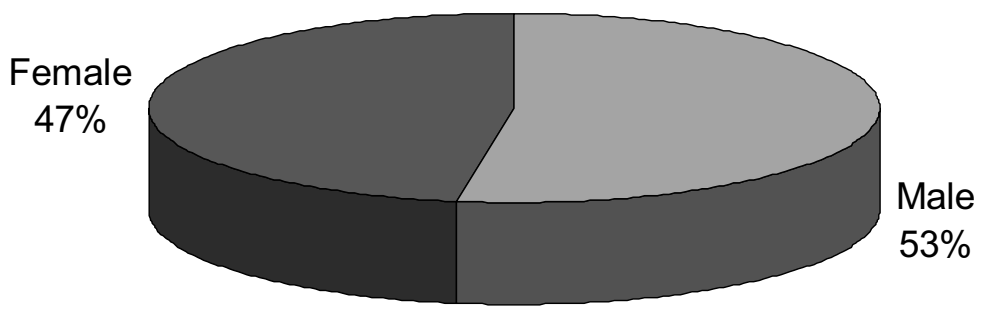

Figure 1 Pie chart showing the distribution of the respondents by sex

The respondents' modes of study are mainly sandwich (during vacation) and weekend programmes. Sandwich candidates are chiefly primary and secondary school teachers who use their holidays for further studies. Weekend programme candidates are workers and those respondents who fall between age 20-24 years. This latter group chose weekend programmes due for one reason or the other. Also, the respondents' level of studies ranges from 100 to 600 . Part-time/ sandwich candidates spend a year more than their counterparts on the full-time programme. That is, a 4-year programme at full-time level will take 5 years part-time. From the data gathered, the majority of the respondents (I,300 representing $26 \%$ ) are in the 400 level; $20.44 \%$ are in the 300 level. Levels of study of other respondents are 100 levels: 720 students, 200 level: 8 I I students (16.220\%), 500 level: 833 students (6.26\%). 


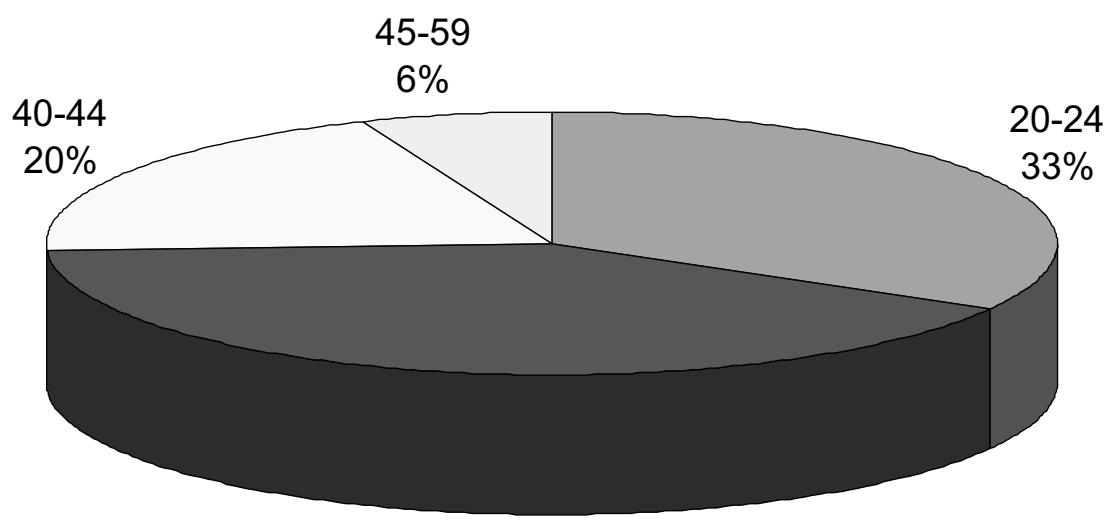

25-39

$41 \%$

Figure 2 Pie chart showing the distribution of respondents by age group

Table 3 Distribution of respondents by mode of studies $(\mathrm{N}=4999)$

\begin{tabular}{|l|c|c|}
\hline \multicolumn{1}{|c|}{ Mode } & Frequency & Percentage \\
\hline Vacations (sandwich & 1720 & 34.41 \\
\hline Weekends (part-time) & 3279 & 65.59 \\
\hline Evening (part-time) & - & - \\
\hline Total & 4999 & 100 \\
\hline
\end{tabular}

Table 4 Distribution of respondents by level of studies $(N=4999)$

\begin{tabular}{|l|c|c|}
\hline \multicolumn{1}{|c|}{ Level } & Frequency & Percentage \\
\hline 100 & 720 & 14.40 \\
\hline 200 & 811 & 16.22 \\
\hline 300 & 1022 & 20.44 \\
\hline 400 & 1300 & 26.00 \\
\hline 500 & 833 & 16.62 \\
\hline 600 & 313 & 6.26 \\
\hline Total & 4999 & 100 \\
\hline
\end{tabular}

Furthermore, their courses of study cut across disciplines in the Arts, Agriculture, Education, Science, Social Science, and Technical Education. Engineering and Technology, Law, Medical sciences and Pharmaceutical sciences are left out. These 
courses are not available on a part-time basis in the universities. See Table 5 for the distribution of the respondents by discipline. Their reasons for opting to pursue their choice course on part-time/sandwich basis were as follows:

- Job demand/constraints (3,009 respondents, 60.19\%)

- Inability to secure full-time studies (I036 respondents, $20.83 \%$ )

- Marriage demand/constraints (845 respondents, 16.80\%)

- Flexibility of part-time/sandwich programmes (109 respondents, $2.18 \%$ ).

Table 5 Distribution of respondents by disciplines $(\mathrm{N}=4999)$

\begin{tabular}{|l|c|c|}
\hline \multicolumn{1}{|c|}{ Discipline } & Frequency & Percentage \\
\hline Arts & 509 & 10.18 \\
\hline Education/Applied Education & 728 & 14.56 \\
\hline Engineering \& technology & - & - \\
\hline Agricultural Sciences & 318 & 6.36 \\
\hline Law & - & - \\
\hline Medical sciences & - & - \\
\hline Sciences & 672 & 13.44 \\
\hline Social sciences & 1037 & 20.74 \\
\hline Management sciences & 1376 & 27.52 \\
\hline Vocational and technical education & 359 & 7.20 \\
\hline Total & 4999 & 100 \\
\hline
\end{tabular}

Table 6 Respondents' reasons for opting for part-time/sandwich programme $(\mathrm{N}=4999)$

\begin{tabular}{|l|c|c|}
\hline \multicolumn{1}{|c|}{ Reason } & Frequency & Percentage \\
\hline Marriage demands/constraints & 845 & 16.80 \\
\hline Job demands/constraints & 3,009 & 60.19 \\
\hline Inability to secure full-time studies & 1,036 & 20.83 \\
\hline Flexibility of part-time/sandwich programmes & 109 & 2.18 \\
\hline Desire for higher education & - & - \\
\hline Total & 4999 & 100 \\
\hline
\end{tabular}

Table 7 Library and information resources known to the respondents $(N=4999)$

\begin{tabular}{|l|c|c|}
\hline \multicolumn{1}{|c|}{ Resources } & Frequency & Percentage \\
\hline Reference sources & 4999 & 100 \\
\hline Textbooks/monographs & 4999 & 100 \\
\hline Serials publications & 4999 & 100 \\
\hline Audio-visual resources & 589 & 11.78 \\
\hline Electronic resources & 2,312 & 46.26 \\
\hline Internet facilities & 4999 & 100 \\
\hline Reprographic facilities & 4999 & 100 \\
\hline
\end{tabular}


An attempt was made in this study to determine the information sources known to the respondents. Analysis of their responses revealed multiple responses; the respondents ticked more than one option. However, their responses also revealed that they are quite conversant with library resources. (See Table 7). Their information format preferences show that they prefer information sources in both print and electronic formats. I,978 respondents $(39.57 \%)$ attested to this. $2,04 \mathrm{I}$ respondents (40.83\%) prefer printed resources only, and 980 respondents requested electronic/audio-visual resources only (see Table 8).

Table 8 Respondents information sources format preference $(\mathrm{N}=4999)$

\begin{tabular}{|l|c|c|}
\hline \multicolumn{1}{|c|}{ Format } & Frequency & Percentage \\
\hline Printed resources only & 2,041 & 40.83 \\
\hline Electronic/AV resources only & 980 & 19.60 \\
\hline Both printed/electronic/AV Resources & 1978 & 39.57 \\
\hline Total & 4999 & 100 \\
\hline
\end{tabular}

Table 9 Information needs of the respondents $(\mathrm{N}=4999)$

\begin{tabular}{|l|c|c|}
\hline \multicolumn{1}{|c|}{ Information Needs } & Frequency & Percentage \\
\hline Information on their course of studies & 4999 & 100 \\
\hline Information on health, politics, economy, trade and commerce & 4,951 & 99.04 \\
\hline Information on career development and job opportunities & 4999 & 100 \\
\hline Information on academic development and scholarship & 3,692 & 73.85 \\
\hline Information on self development and problem solving & 3,886 & 77.74 \\
\hline Information relating to professions and professional activities & 4,712 & 94.26 \\
\hline Information on current and issues & 3,009 & 60.19 \\
\hline
\end{tabular}

Table 10 Impediments to utilization of library resources and facilities $(N=4999)$

\begin{tabular}{|l|c|c|}
\hline \multicolumn{1}{|c|}{ Impediments } & Frequency & Percentage \\
\hline Inadequate library facilities & 1259 & 25.20 \\
\hline Paucity of desired resources & 1,054 & 21.08 \\
\hline Lack of time due to the intensive nature of the programmes & 1,099 & 21.98 \\
\hline Inadequate library use skill & 344 & 6.88 \\
\hline Absence of electronic resources in the libraries collection & 589 & 11.78 \\
\hline Heavy reliance on lecture/study packs provided by the universities & 654 & 13.08 \\
\hline Total & 4999 & 100 \\
\hline
\end{tabular}

Table I I Information searching and ICT skills possession by the respondents $(N=4999)$

\begin{tabular}{|l|c|c|}
\hline \multicolumn{1}{|c|}{ Skill } & Frequency & Percentage \\
\hline Excellent & - & - \\
\hline Good & 980 & 19.60 \\
\hline Fair & 2,096 & 41.93 \\
\hline Poor & 1923 & 38.47 \\
\hline Desire for higher education & - & - \\
\hline Total & $\mathbf{4 9 9 9}$ & 100 \\
\hline
\end{tabular}

Inkanyiso, Jnl Hum \& Soc Sci 2010, 2(2) 
The information needs of the respondents are diverse, and vary from information on their course of study, career development, to information on current affairs and politics (see Table 9). However, the respondents' views on the extent to which their university libraries provide for their information needs reveal a needy state. From the researcher's views and judgement, library services for the sandwich/part-time students of the institutions are less than adequate, and their services below expectations. The situation in OOU is a bit better than that of TASUED. OOU has two scantly stocked libraries to provide for part-time/sandwich students at two study centres (ljebu-Ode and ljebu-lgbo) TASUED has none for them, whereas it has 4 study centres for its students. However, the institution expects the students to visit its main campus library for their information needs. Also, while OOU has six other libraries students can use, TAUSED has only one, its main library.

There are other impediments to the respondents meeting their information needs, and to the utilization of library and information resources. These impediments in order of priority, among others, are:

- Inadequate library facilities (I259 respondents, 25.20\%),

- Lack of time due to the intensive nature of the programme (1099 respondents, $21.98 \%)$,

- Paucity of desired resources ( 1054 respondents, $21.08 \%)$, and;

- Reliance on study packs/materials. (654.13.08\%) (see Table I0).

The study in conclusion sought to determine the ICT skills and information searching abilities of the respondents. The majority, 2096 respondents (4I.93\%), rated themselves fair. 1923 respondents (38.47\%) considered themselves poor, and only 980 respondents thought they are good (see Table II).

\section{Conclusion and recommendations}

Based on this study's findings, sandwich/part-time students represent both sexes, they are of 20-59 years age range, and they have reasons for undertaking part-time/sandwich academic programmes. Among these reasons are job demand/ constraints, and flexibility of the programme. Part-time/sandwich students' courses of study include arts, social sciences, sciences, and applied sciences; and their information needs relate mainly to their respective disciplines, and other political and economic issues.

They are quite aware of the library and its resources to meet their information needs. However, the libraries and their services, in their judgement, fall short of their expectations. Other impediments to the respondents' information needs are inadequate library facilities and reliance on study packs provided by the institutions. Absence of ICT and information searching skills among the students also account for their problems in accessing information. This has resulted in their inability to use electronic resources available through the Internet, and to search their libraries for information sources.

Arising from this conclusion, the following recommendations are proffered:

- The University should recognize the rights of the students to access accurate information in desirable formats. As such, the universities should make library services available to the students in their various study centres. Also, the universities can enter into some arrangements with public and secondary school libraries within their domain for space to stock tertiary texts for the benefits of part-time/sandwich students.

- The students' ICT and library use skills can be enhanced through the provision of adequate practical training. The training will make them information literate, and inculcate the habits of effective use of library resources.

- Acquisitions of or subscription to electronic resources and provision of training to students on how to use them can be adopted by the universities. Electronic resources due to their peculiar advantage over print resources, will go a long way in providing for the information needs of the students. Also the problem of paucity of desired information sources will be drastically taken care of. The students, with the appropriate access codes, can make use of the eresources in their respective homes, offices, etc.

- In order to encourage library use and exposure of sandwich/part-time students to varieties of information, the study packs provided by the school should be reviewed. The packs should contain bibliographies of relevant sources, assignments that can make the students visit libraries, and the packs should not answer review questions.

- Provision of bookshop services at reduced prices. The universities can consider these for their study centres. Greater availability of textbooks and information sources to the students shall to some extent assist in meeting their information needs and at the same time generate some income for the universities.

\section{References}

ACRL Standard and Guidelines. 2000: Guidelines for Distance Learning Library Services C \& RL News 6I (I I): I023-1029.

Aramide, K. A. and I. A. Ayanlola 2008: ICT application and utilization for distance and open learning education at the National Open University of Nigeria (NOUN). NIGERIAN School Library Journal.

Ault. M. 2002. Thinking Outside the Library: how to develop, implement and promote library services for distance learners. Journal of Library Administration 37 (I/2): 39-48.

Barron, B. B. 2002: Distant and distributed learners are two sides of the same coin. Computers in Libraries 22:26. 
Boadi, B. V. and P. Letsolo 2004: Information needs and information seeking behaviour of distance learners at the institute of extra-moral studies in Lesotho. Information Development 20(3): 189-199.

Cassner, M. and K. Adams 1998: Instructional support to a rural graduate population: an assessment of library services. In the fifth off-campus library services conference proceedings, ed C. J. Jacob, 455-462. Mount Pleasant, MI: Central Michigan University.

Cooke, N. A. 2004: The role of librarians in web-based distance education: an account and an analysis of the impact of web technology on distance learning - what remains unchanged, what is changing. Journal of Library and Information Services in Distance Learning I (4): 47-57.

Gopakumar, V. and A. Barado 2009. Assuring quality in distance education for library and information science. The role of the Library. Library Philosophy and practice. Available at http://www.webpages Uidaho.edu/mbolin (accessed 2 June 2009 ).

Jaggen, K. E., E. M. Tallrnan, and W. B. Wadeell 1994: Library services to off-campus sites: An assessment survey. In the seventh off-campus library services conference proceedings, ed. C. J. Jacob, I3I-I35. Mount pleasant, MI Central Michigan University.

Kalvuya, J. M 2004. University Libraries in Kenya: A study of their practices and performance. Ph.D Thesis. Institute of Library Science, Humboldt University Berlin . 320p.

Kelley, K. B. and 0. J. Orr 2004. Trends in Distant Student use of Electronic Resources: A Survey College and Research Libraries 64(3): $|76-19|$.

Lees, S. D. 2002: Binding an electronic resource collection: A practical grade. London Library Association.

Liu, Z and Z. V. Yang 2004. Factors influencing distance - education graduate students' use of information resources: A user study. The Journal of Academic Librarianship, 30(I): 24-35.

Mabawonku, I. 2004. Library use in distance learning: a survey of undergraduates in three Nigerian Universities. African Journal of Library, Archives and Information Science, I4(I); I5I-I66.

Mclean, E. and S. H. Dew 2004. Assessing the Library needs and preferences of off-campus students: Surveying distance education students from the Midwest to the West ladies. Journal of Library Administration 4I (I/2): 265-302.

Neimi, J. A., B. J. Ehrard, and L. Neeley 1998: Off-campus library support for distance adult learners. Library Trends, 47 (I) I47.

Newton, Robert. 2007: Developing information (iterate off-campus learners: pedagogical issues and current practice. Libri 57 (3): 140-164.

Oladokun, O. S. and L. O. Aina 2009: Library and information needs and barriers to the use of information sources by continuing education students at the University of Botswana. Information Development, 25 (4). Available at $h t t p: / / / d v$ sagepub.com/cgi/contentlabstract/25/I/43 (accessed 25 August 2009).

Samaila, J. 2008: Strengthening the capacity of distance education in the training of teachers to achieve the millennium development goal on education in Nigeria. International Journal of Research in Education, 5 (I \& 2): 269-278.

Shale, D. and J. Gomes 1998: Performance indicators and University Distance Education Providers. Journal of Distance Education, 8(4): 12-25.

Shouse, D. L. 1995: Library needs of rural distance education students. In the seventh off-campus library services conference proceedings, ed. C. J. Jacob, 355 - 382. Mount pleasant, MI: Central Michigan University.

Singh, B. 1997: The practice and management of distance education. Journal of Distance Education, 8(4): $42-54$.

Stasch, M. 1994. A survey of information sources used by students involved in distance education. MLS. Thesis. USA: San Jose State University, 48.

Thompson, A. J. 2007: Information seeking behaviour of distance education students. MLIS thesis. North Carolina: University of Nuth Carolina at Chapel Hill, 48p.

Unwin, L. K. Stephens, and N. Bolton 1998: The role of the library in distance learning. A study of postgraduate students, course-providers and librarians in the UK. London: Bowker Saur. 